\title{
Author Correction: P53 and mTOR signalling determine fitness selection through cell competition during early mouse embryonic development
}

\author{
Sarah Bowling 1,2,3, Aida Di Gregorioํ, Margarida Sancho ${ }^{1}$, Sara Pozzi ${ }^{4}$, Marieke Aarts ${ }^{2,3}$, Massimo Signore ${ }^{4}$, \\ Michael D. Schneider (1) ${ }^{1}$, Juan Pedro Martinez-Barbera ${ }^{4}$, Jesús Gil ${ }^{2,3}$ \& Tristan A. Rodríguez (1) ${ }^{1}$
}

Correction to: Nature Communications; https://doi.org/10.1038/s41467-018-04167-y; published online 02 May 2018.

The original version of this Article contained an error in the spelling of Juan Pedro Martinez-Barbera, which was incorrectly given as Juan Pedro Martinez Barbera. This error has now been corrected in both the PDF and HTML versions of the Article.

Published online: 02 August 2018

\begin{abstract}
(c) Open Access This article is licensed under a Creative Commons Attribution 4.0 International License, which permits use, sharing, adaptation, distribution and reproduction in any medium or format, as long as you give appropriate credit to the original author(s) and the source, provide a link to the Creative Commons license, and indicate if changes were made. The images or other third party material in this article are included in the article's Creative Commons license, unless indicated otherwise in a credit line to the material. If material is not included in the article's Creative Commons license and your intended use is not permitted by statutory regulation or exceeds the permitted use, you will need to obtain permission directly from the copyright holder. To view a copy of this license, visit http://creativecommons.org/licenses/by/4.0/.
\end{abstract}

(C) The Author(s) 2018

\footnotetext{
${ }^{1}$ British Heart Foundation Centre for Research Excellence, National Heart and Lung Institute, Imperial Centre for Translational and Experimental Medicine, Imperial College London, Hammersmith Hospital Campus, Du Cane Road, London W12 ONN, UK. ${ }^{2}$ Cell Proliferation Group, MRC London Institute of Medical Sciences (LMS), Du Cane Road, London W12 ONN, UK. ${ }^{3}$ Cell Proliferation Group, Institute of Clinical Sciences (ICS), Faculty of Medicine, Imperial College London, Du Cane Road, London W12 ONN, UK. ${ }^{4}$ Developmental Biology and Cancer Programme, Newlife Birth Defects Research Centre, UCL Great Ormond Street Institute of Child Health, 30 Guilford Street, London WC1N, UK. Correspondence and requests for materials should be addressed to

J.G. (email: jesus.gil@imperial.ac.uk) or to T.A.Ríg. (email: tristan.rodriguez@imperial.ac.uk)
} 